\title{
Risk Analysis of China's Internet Finance and Strategies
}

\author{
Libin Xie \\ Department of Business Administration \\ Fuzhou University of International Studies and Trade \\ Fuzhou, China
}

\begin{abstract}
In recent years, China's Internet finance has been developing rapidly. Compared with the traditional financial industry, Internet finance enjoys advantages of low cost, high efficiency, wide coverage and rapid development. At the same time, China's Internet finance has a large risk hidden danger. Starting from the characteristics of Internet finance, this paper analyzes the current situation of Internet finance, analyzes the risks of Internet finance, and puts forward some financial management countermeasures and risk prevention mechanisms to promote the development of China's Internet finance industry in a better and faster way.
\end{abstract}

Keywords-Internet finance; financial risk; prevention mechanism

\section{INTRODUCTION}

\section{A. Research Background and Significance}

In recent years, the Internet has developed rapidly. Traditional financial institutions such as banks and fund companies have used the Internet to consolidate their own status and broaden their business areas. Internet companies such as Alibaba, Baidu, Suning, and Jingdong have also entered the financial business through the Internet, breaking the tradition. The financial pattern of ideas has changed people's financial management concepts.

But new things have two sides. Even after the development of the Internet for a decade or two, risks have always been controversial, not to mention Internet financial risks. Although the combination of Internet and finance provides people with more efficient and diversified investment and financing means, it also carries higher risks. Internet financial changed people's concept of consumption and investment, have broken the traditional financial industry on behalf of the banking business and service, but because of the limitations of its own technology, system and other aspects and produce negative risk also caused the wide attention of the society, so to better prevention and control financial risks, and the Internet financial regulatory system and a corresponding laws, regulations, safeguard measures of innovation is imperative.

\section{B. The Concept of Internet Finance}

Internet finance refers to a new financial business model in which traditional financial institutions and Internet companies use Internet technology and information and communication technologies to achieve financial, financial, payment, investment and information intermediary services. Internet finance is not a simple combination of the Internet and the financial industry, but a new model that is naturally adapted to new demands after being familiarized and accepted by users (especially for the acceptance of ecommerce) at the level of network technology such as security, mobile and new business. From the perspective of user needs, there is no real difference between Internet finance and traditional finance, which can meet the basic business needs of users for deposits, loans, remittances, and investment and financing.

\section{Characteristics of Internet Finance}

1) Wide coverage: The advantage of the Internet is that it can break through time and geographical restrictions, so that people who are thousands of miles away can get together. The Internet finance model satisfies the demand for people to find funds on the Internet, covers the traditional financial service blind spots, makes financial services more extensive, and financial transactions are more direct.

2) Rapid development: In this era of constant innovation, the speed of the Internet has determined the constant innovation of Internet finance. On the basis of continuous improvement of big data and e-commerce, the future Internet finance will evolve more models, and will more fully meet the needs of users and realize the true Internet economy.

3) Low cost: Under the Internet financial model, both the supply and demand sides of funds can complete information screening, matching, pricing and trading on their own through the network platform, without traditional intermediary, no transaction costs, and no monopoly profits. On the one hand, financial institutions can avoid the capital investment and operating costs of opening outlets; on the other hand, consumers can quickly find suitable financial products on an open and transparent platform, which reduces the degree of information asymmetry and saves time and effort. 
4) Weak supervision: First, the wind control is weak. Internet finance has not yet accessed the People's Bank of China credit information system, and there is no credit information sharing mechanism. It does not have similar bank risk control, compliance and collection mechanisms, and is prone to various types of risk problems. Some P2P online loan platforms have already existed. Announce bankruptcy or stop service. Second, the supervision is weak. Internet finance is in its infancy in China. There are no regulatory and legal constraints, lack of access thresholds and industry norms. The entire industry faces many policy and legal risks.

5) Digital technology driving characteristics are further obvious: The big data technology is widely used in customer portrait, precision marketing, risk control and other fields. Cloud computing plays an important role in satisfying the diversified services of long tail customers with its advantages in system architecture, resource integration and other aspects. The application effect of artificial intelligence technology is beginning to appear, and the application of biological identification technology in authentication, payment and other scenarios is gradually increasing.

\section{THE DEVELOPMENT MODEL OF CHINA'S INTERNET FINANCE}

There are many Internet financial models in China, including third-party payment platforms, P2P lending platforms, online credit platforms, crowd-funding platforms, big data finance and Internet finance portal.

\section{A. Third-party Payment Platforms}

Third-party payment refers to an independent organization with certain strength and credit guarantee, which facilitates the online payment mode of transactions between the two parties through docking with the network. In the third-party payment mode, after the buyer purchases the goods, the account provided by the third-party platform is used for payment (payment to a third party), and the third party notifies the seller of the payment to the account and requests the delivery; the buyer receives the goods and inspects the goods. And after confirming, notify the third party to pay; the third party then transfers the money to the seller's account.With the rise of third-party payments, more and more people are accustomed to using their own smart devices to pay for their daily lives. Third-party payment has become the consumption port of most users, and has accumulated a large amount of user consumption data for Internet finance companies. Third-party payment has become a must for Internet finance because of its high frequency of demand.

\section{B. P2P Lending Platforms}

The $\mathrm{P} 2 \mathrm{P}$ network lending platform is a financial model in which individuals provide small loans to other individuals through a third-party platform under the premise of charging certain interest. The customer objects include two types: one is the customer who lends the funds, and the other is the need. Through this kind of lending, the $\mathrm{P} 2 \mathrm{P}$ network lending platform can alleviate the imbalance of consumption power caused by the uneven income at different stages, so that more people can enjoy the P2P microfinance service. As of August 1, 2018, China had $551 \mathrm{p} 2 \mathrm{p}$ online lending platforms licensed by ICP. Despite the large number of online platforms, many platforms have problems such as lack of funds, imperfect website structure, and opaque information.

\section{Online Credit Platform}

Network credit business is an important area of Internet finance development. In the online credit business, Alibaba Finance has been at the forefront of the industry. Alibaba.com uses the network platform to utilize cloud computing capabilities and big data technology, relying on a huge network to statistically organize its data resources, and establish a loan evaluation system with a number of indicators such as favorable rate and complaint rate. Use this as a scientific basis for loan business. The lender can register the loan, register the loan application, submit the loan application form and relevant supporting documents, and then issue the loan through the loan evaluation system and face-to-face audit investigation. This platform has low cost, fast speed, low threshold and high safety factor, which can better meet the loan demand of SMEs.

\section{Online Crowd-funding Platform}

Crowd-funding is a "pre-consumption" model that raises project funds to the public in the form of "group purchase + pre-order" . Crowd-funding uses the characteristics of the Internet and SNS to allow small entrepreneurs, artists or individuals to show their ideas to the public, to get everyone's attention and support, and then to get the financial assistance needed. Compared with traditional financing methods, Crowd-funding is more open, and the ability to obtain funds is no longer based on the commercial value of the project. As long as it is a project that the public likes, the first fund can be obtained through Crowd-funding, and the scale of the first fundraising will not be large, providing unlimited possibilities for more small businesses or creative people. The Crowd-funding platform is divided into rewarded Crowd-funding, public welfare Crowd-funding, equity Crowd-funding and debt Crowd-funding.

\section{E. Big Data Finance}

Big financial data collection refers to the vast amounts of unstructured data, through carries on the real-time analysis, can provide customers comprehensive information for the Internet that financial institutions, through the analysis and mining and trading and consumption information, grasp the customer's spending habits, and predict customer behavior, financial institutions and financial services platform targeted in terms of marketing and risk control. A new wave that is changing the way we live, work and think is creeping up on us: big data. 


\section{F. Internet Finance Portal}

Internet financial portal refers to a platform that USES the Internet to sell financial products and sell financial products to provide third-party services. Its core is the mode of "search + price comparison". It adopts the vertical price comparison method of financial products and puts the products of various financial institutions on the platform. Users can compare and cancel appropriate financial products. The diversified and innovative development of Internet financial portals has formed a third-party financial management institution that provides high-end financial investment services and financial products.

\section{MAJOR RISKS OF CHINA'S INTERNET FINANCE}

Since China's Internet finance belongs to new formats and new models in the financial field, the current laws, policies, and regulatory systems are not sufficient to completely cover Internet risk loopholes. The industry is still in a barbaric growth stage, and China's Internet finance is also facing more risks.

\section{A. Transaction Risk}

Trading risks include trading system risks and trading characteristics risks. Trading system risk refers to the inability of an organization to provide a secure product or service, such as phishing, virus threats, system outages, or other unforeseen events. This risk exists in every Internet financial product or service. The characteristics of Internet financial transaction risk arise from the decision-making of economic entities, mainly due to the credit risk caused by information asymmetry between traders, and of course market risk and liquidity risk. The credit risk mainly refers to the lack of network credit information system construction, information opacity and lack of credit information leading to trust crisis and risk aggregation.

\section{B. Technical Risk}

Internet technology itself has technical risks, including technical security and technical capacity of trusted information systems, hacking, password leakage, and theft of account funds. Trader identity and authenticity are difficult to confirm, and there is a high risk of consumer information disclosure and fraud and deception. Compared with the closed business system of the bank, the user sensitive information and personal property of Internet finance have greater security risks, and accelerate the spread of risks such as payment and liquidation, making the risk transfer between non-traditional financial institutions and traditional financial institutions.

\section{Cognitive Risk}

The innovation of internet finance lies in the creation of new business technologies, trading channels and methods. The main functions are still finance, financial discovery, payment and settlement, etc. The two core vocabularies of the financial industry are funds and risks, but due to Internet expansion. The financial transaction possibility boundary, a large number of people not covered by traditional finance are included in the scope of financial services. This part of the population is relatively lacking in risk identification ability and risk tolerance, and individual and collective irrationality are more likely to appear, which increases the probability of risk occurrence.

\section{Information Risk}

Most transactions in the Internet finance field require verification and certification of the identity information, property status and credit records of the two parties. Under the current unsound condition of China's credit system, the "not present" of the two parties makes the asymmetry Information-related adverse selection and moral hazard issues are more likely to occur than traditional financial industries. On the one hand, because consumers can't identify the quality of many endless Internet finance companies, products and services, most of them estimate the expected price based on the industry average, which may lead to the phenomenon of "bad money expelling good money" and "lemon market". On the other hand, Internet companies will also use consumers' awareness of the "vacuum" of the operation mode of products and services, infringe on the interests of the latter, and even carry money to "run the road." In reality, there are also a large number of cases in which a party in a transaction uses the concealment of information in the process of Internet transactions to engage in illegal activities such as fraud and money laundering.

\section{COUNTERMEASURES AND SUGGESTIONS}

Compared with traditional finance, Internet finance provides people with a more time-saving and labor-saving lifestyle, but its risk is higher than traditional financial risks. Based on the analysis of the development status and potential risks of Internet finance, this paper proposes the following countermeasures for Internet financial risk management:

\section{A. Improving the Legal System of Internet Finance}

Improve existing laws and regulations, but not to stifle the innovation power of Internet finance. At the same time, we must ensure that industry regulations effectively regulate the behavior of the industry. This requires that the regulations of the Internet financial industry should be consulted when formulating regulations and the Internet should be continuously Finance conducts follow-up investigations. Modify existing financial laws and regulations according to the characteristics of Internet finance. Including securities law, commercial banking law, insurance law and bank supervision and management law and other related laws. At the same time, we must constantly refine and introduce the corresponding legal rules according to the reality of China's Internet finance development, and make detailed and specific explanations and supplementary explanations on the legal system within the framework to make up for the loopholes and defects of the original law. 


\section{B. Strengthening the Construction of Credit System for Internet Finance}

In view of the lack of credit system, rating agencies should evaluate the credit measurement of users and Internet financial platforms to improve the reliability and creditworthiness of their Internet financial transactions. First, it is necessary to evaluate the legality, technical conditions, management level, financial status and other indicators of the Internet financial platform to determine whether the financial institution has market access qualifications, whether there is a licensed license, and whether its operating mechanism and technology can support the entire The operation of the system, reviewing its assets and liabilities and the flow of funds and other indicators to ensure that the platform has qualified Internet financial products operating qualifications, can grasp the ability of risk prevention and control.

\section{Strengthening the Education and Protection of Internet Financial Participants}

On the one hand, Internet finance participants are investors. They should fully remind them of the risks of investing in Internet financial products. In particular, they should reveal to them that such risks are much higher than the risks of traditional financial products and help them establish a sense of risk prevention. On the other hand, Internet financial participants are also consumers. For their legitimate legitimate rights and interests, they should increase protection and establish practical protection measures.

\section{Improving Internet Financial Security Technology}

First, based on the mature network identity authentication system in the banking sector, the Internet financial certification system should be further improved, and a secure and credible website authentication system should be established to ensure the authenticity of the website. Second, we must vigorously develop information technology equipment with independent intellectual property rights, improve the level of key technologies of computer systems and the security defense capabilities of key equipment to prevent theft of customer data, theft of client funds, and malicious attacks from inside and outside the network. The event happened. Third, security monitoring and security controls should be used to ensure the smooth operation of Internet financial transactions, and electronic authentication and signature technology should be introduced when conducting Internet financial services to ensure the authenticity of the information of all parties involved.

\section{E. Strengthening Industry Norms}

Strengthen industry risk management and control through the Internet Finance Industry Association. In 2016, China Internet Finance Industry Association was formally established. This is a true Internet financial self-regulatory organization, which is of great significance for regulating the development of Internet finance. For a long time, China's industry supervision has always had semi-official characteristics. The government is not an industry professional institution to conduct industry supervision, and the effect is not satisfactory. The Internet Finance Industry Association is an industry regulatory body formed by financial enterprises spontaneously. It has no government officials to serve and is fully accredited by the government. Industry experts and industry development methods based on Internet financial market selection can effectively reduce the incidence of Internet financial risks.

\section{CONCLUSION}

Internet finance is the transformation and upgrading of the traditional financial industry, and the business model and industry risks derived from it bring us great opportunities and challenges. In order to promote the innovative development of Internet finance, it is necessary to combine China's actual situation, draw on foreign experience, put forward countermeasures to prevent risks and strengthen supervision and prevention.

\section{REFERENCES}

[1] Li X, Economics S O, University P. Analysis of Internet Financial Risks and Suggestions for Supervision[J]. Management \& Technology of Sme, 2018

[2] Xiaoqiu W U. Internet Finance:The Logic of Growth[J]. Finance \& Trade Economics, 2015.

[3] Li Y, Chen F, Jin Y, et al. A Study on the Regulation of the Internet Finance[J]. Journal of Zhejiang University, 2014, 37(99):107 - 115

[4] Lin T. The risk and prevention of internet finance[C]// International Conference on Industrial Economics System and Industrial Security Engineering. IEEE, 2017.

[5] Wang B, Zheng L S, Wang Z B. The Analysis and Regulation of Internet Finance Risk--From the Perspective of Overall National Security $[\mathrm{J}]$. Technoeconomics \& Management Research, 2018.

[6] Zhao Z Q. Internet Finance and Its Risk Prevention and Control[J]. Taxation \& Economy, 2018. 